\title{
ASSOCIATION BETWEEN HELICOBACTER PYLORI CONCENTRATION AND THE COMBINING FREQUENCY OF HISTOPATHOLOGICAL FINDINGS IN GASTRIC BIOPSIES SPECIMENS
}

\author{
Gisele Alborghetti NAI'1 , Ana Carolina Gomes PARIZI ${ }^{2}$ and Ricardo Luís BARBOSA ${ }^{3}$
}

\begin{abstract}
Background - Helicobacter pylori is the most prevalent infectious agent worldwide. About $90 \%$ of patients with chronic gastritis are infected with this bacterium. Some studies have shown a association between the H. pylori concentration and the scores of gastritis activity and severity. Aim - To evaluate the association between $H$. pylori concentration and the combining frequency of findings on histopathological examination. Methods - Two hundred consecutive gastric endoscopic biopsies diagnosed as chronic gastritis were retrospectively investigated. The Warthin-Starry silver stain was used to study H. pylori and the following parameters were assessed (according to the Sydney system): 1. infiltration by polymorphonuclear cells in chorio and epithelium (activity) graded as mild, moderate and marked; 2. presence of lymphoid follicles; 3 . presence of intestinal metaplasia; 4. presence of regenerative cell atypias, graded as mild, moderate and marked; and 5. H. pylori concentration on the mucous covering the foveolar epithelium. Results - The most frequent association was chronic gastritis and activity, regardless of $H$. pylori concentration. The association of five histopathological findings in the same biopsy has not occurred in the cases of higher concentration of H. pylori. Conclusion - Our study has not revealed any association between $H$. pylori concentration and an increasing in the number of histopathological findings found in the gastric mucosa. Since referring to its presence is much more important than to its concentration.
\end{abstract}

HEADINGS - Gastritis. Helicobacter pylori. Helicobacter infections. Biopsy.

\section{INTRODUCTION}

Since it was firstly described by Warren and Marshall in 1983, Helicobacter pylori (H. pylori) etiologic relevance has been emphasized ${ }^{(17,18)}$ in many gastrointestinal tract and esophageal diseases as being reported to cause gastritis, peptic ulcers, dysplastic lesions, gastric adenocarcinoma, gastric lymphomas ${ }^{(7,8,12,14,17,19,22)}$ and a possibly cause of non-ulcer dyspepsia ${ }^{(7)}$.

In developing countries, the infection is acquired during childhood, compromising around $90 \%$ of the population. In developed countries, the prevalence is influenced by age, race, and socioeconomic status of the population studied ${ }^{(14,16,22)}$.

Histopathological findings of the gastric mucosa due to H. pylori infection are mononuclear infiltrate, infiltration by polymorphonuclear cells in the corium and epithelium (activity), presence of lymphoid follicles, intestinal metaplasia and regenerative cell atypias ${ }^{(2,3,4,5,8,9,11)}$. The inflammatory response is different in adults and children.
Some studies have shown an association between H. pylori concentration and the gastritis severity and

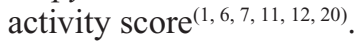

The aim of this study was to investigate the association between $H$. pylori concentration and the combining frequency of histopathological findings in gastric biopsies.

\section{METHODS}

A retrospective analysis on 200 consecutive endoscopic gastric biopsies diagnosed as chronic gastritis by the Laboratory of Pathology from the Hospital "Dr. Domingos Leonardo Cerávolo", Paulista West University (UNOESTE), Presidente Prudente, SP, Brazil, was carried out during January 1993 to March 2000.

Biopsy specimens were collected from 110 male and 90 female patients whose ages ranged from 20 to 86 years. All biopsies were done to investigate the cause of gastritis and its grade of activity, to plan the patients' treatment.

The present study was carried out in the Department of Pathology, School of Medicine, Paulista West University - UNOESTE, Presidente Prudente, SP, Brazil.

1 Department of Pathology; ${ }^{2}$ School of Medicine, Paulista West University - UNOESTE. Presidente Prudente, SP; ${ }^{3}$ Faculdades Associadas de São Paulo - FASP São Paulo, SP, Brazil.

São Paulo, SP, Brazil.

Prudente, SP, Brazil. E-mail: patologia@unoeste.br. 
One hundred and seventy five biopsies were obtained from the antral region and 25 from the gastric fundus-corpus region.

Paraffin embedded biopsy specimens were cut into histological sections and stained with hematoxylin and eosin (H-E) and Warthin-Starry (WS) silver staining, and analyzed by one single pathologist (GAN).

The following parameters were evaluated: 1 .infiltration by polymorphonuclear cells in the corium and epithelium graded into mild, moderate and marked according to the Sydney system ${ }^{(4)}$; 2. presence of lymphoid follicles; 3 . presence of intestinal metaplasia; 4. presence of regenerative cell atypia graded into mild, moderate and marked; and 5. H. pylori concentration on the mucus layer overlying the foveolar epithelium graded as $1+$ for mild, $2+$ for moderate and $3+$ for marked, according to the Sydney system ${ }^{(4)}$.

Isolated findings were firstly assessed and further combined for $H$. pylori concentration.

Statistical analysis was carried out by non parametric variance analysis (Kruskal-Wallis test) to evaluate the association between histopathological findings and H. pylori concentration.

\section{RESULTS}

Among the 200 biopsies evaluated, 83 (41.5\%) were negative for $H$. pylori and 117 (58.5\%) were $H$. pylori positive. Among these biopsies, 71 revealed a bacterial concentration of $1+, 27$ revealed concentrations of $2+$, and 19 revealed a $3+$ concentration.

Figure 1 shows a comparison between histopathological findings and $H$. pylori concentration.

There was an occurrence of a marked degree of activity in $9.8 \%$ of the cases with $1+$ of $H$. pylori, in $3.7 \%$ with $2+$, in $42 \%$ with $3+$, and $14.4 \%$ were cases without the bacteria $(P=0.03)$ (Figure 2).

Moderate regenerative cellular atypias have occurred in 7\% of the specimens with $1+$ of $H$. pylori, in $14.8 \%$ with $2+$, in $5.2 \%$ for those $3+$, and $1.2 \%$ were cases reported without the bacteria $(P=0.001)$. Marked regenerative cellular atypias were not reported.

Table 1 shows the combination of histopathological findings, and Table 2 shows their combining frequency in the same biopsy related to the presence and concentration of $H$. pylori.

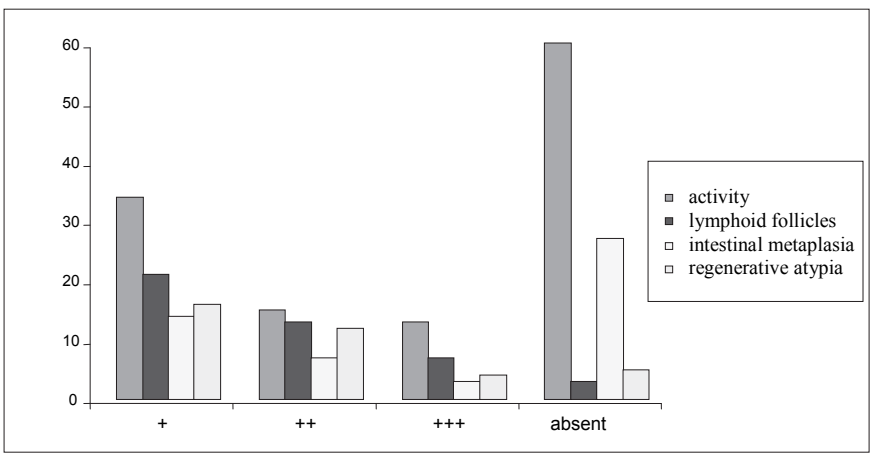

* 1+: mild, $2+$ : moderate and $3+$ : marked. Activity $-P=0.03$; lymphoid follicles $-P=0.001$; intestinal metaplasia

FIGURE 1. Association between histopathological findings and concentration of $H$. pylori in gastric biopsies specimens $(\mathrm{n}=200)$

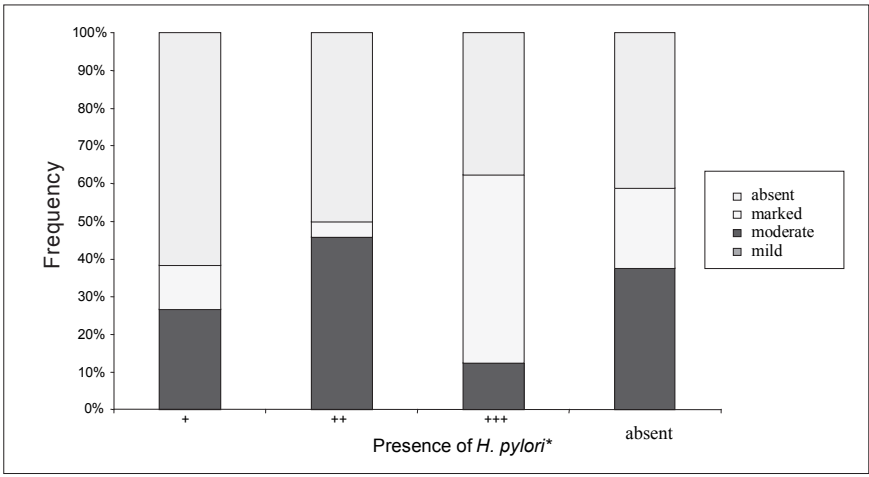

* $P=0,03$

* 1+: mild, 2+: moderate and 3+: marked.

FIGURE 2. Association between the grade of activity and the concentration of $H$. pylori in gastric biopsies $(\mathrm{n}=200)$

TABLE 1. Combination of histopathological findings in the same gastric biopsy specimen in accordance with the concentration of H. pylori $(\mathrm{n}=200)$

\begin{tabular}{|c|c|c|c|c|c|}
\hline \multirow{2}{*}{ Histopathological findings } & \multicolumn{5}{|c|}{ Presence of $H$. pylori* } \\
\hline & Absent & + & ++ & +++ & Total \\
\hline CGO & 15 & 15 & 04 & --- & 34 \\
\hline $\mathrm{CG}+\mathrm{A}$ & 34 & 19 & 02 & 09 & 64 \\
\hline $\mathrm{CG}+\mathrm{LF}$ & 02 & 09 & 03 & 03 & 17 \\
\hline $\mathrm{CG}+\mathrm{IM}$ & 02 & 03 & 01 & --- & 06 \\
\hline $\mathrm{CG}+\mathrm{RCA}$ & 02 & 01 & 02 & 01 & 06 \\
\hline $\mathrm{CG}+\mathrm{A}+\mathrm{LF}$ & 01 & 03 & 01 & --- & 05 \\
\hline $\mathrm{CG}+\mathrm{A}+\mathrm{IM}$ & 24 & 04 & 02 & 02 & 32 \\
\hline $\mathrm{CG}+\mathrm{A}+\mathrm{RCA}$ & 02 & 05 & 03 & --- & 10 \\
\hline $\mathrm{CG}+\mathrm{LF}+\mathrm{IM}$ & --- & 02 & 01 & 01 & 04 \\
\hline $\mathrm{CG}+\mathrm{LF}+\mathrm{RCA}$ & 01 & 05 & 01 & 01 & 08 \\
\hline $\mathrm{CG}+\mathrm{MI}+\mathrm{RCA}$ & --- & 01 & --- & --- & 01 \\
\hline $\mathrm{CG}+\mathrm{A}+\mathrm{LF}+\mathrm{IM}$ & --- & --- & 01 & --- & 01 \\
\hline $\mathrm{CG}+\mathrm{A}+\mathrm{LF}+\mathrm{RCA}$ & --- & --- & 04 & 02 & 06 \\
\hline $\mathrm{CG}+\mathrm{A}+\mathrm{IM}+\mathrm{RCA}$ & --- & 02 & --- & --- & 02 \\
\hline $\mathrm{CG}+\mathrm{LF}+\mathrm{IM}+\mathrm{RCA}$ & --- & 01 & --- & --- & 01 \\
\hline $\mathrm{CG}+\mathrm{A}+\mathrm{LF}+\mathrm{IM}+\mathrm{RCA}$ & --- & 01 & 02 & --- & 03 \\
\hline Total & 83 & 71 & 27 & 19 & 200 \\
\hline
\end{tabular}

CGO - chronic gastritis only/ CG: chronic gastritis/ A: activity/ LF: lymphoid follicles/

IM: intestinal metaplasia/ RCA: regenerative cell atypia. * $1+$ : mild, $2+$ : moderate and
$3+$ : marked. $P>0.005$

TABLE 2. Frequency of combination of histopathological findings in the same gastric biopsy specimen according to the concentration of H. pylori $(\mathrm{n}=200)$

\begin{tabular}{lcccc}
\hline \multirow{2}{*}{$\begin{array}{l}\text { Histopathological } \\
\text { findings }\end{array}$} & \multicolumn{4}{c}{ Presence of H. pylori* } \\
\cline { 2 - 5 } & Absent & + & ++ & +++ \\
\hline CGO & $15(18,07 \%)$ & $15(21,12 \%)$ & $04(14,8 \%)$ & --- \\
2 findings & $40(48,19 \%)$ & $32(45,07 \%)$ & $08(29,62 \%)$ & $13(68,42 \%)$ \\
3 findings & $28(33,73 \%)$ & $20(28,16 \%)$ & $08(29,62 \%)$ & $04(21,05 \%)$ \\
4 findings & --- & $03(4,22 \%)$ & $05(18,51 \%)$ & $02(10,52 \%)$ \\
5 findings & --- & $01(1,4 \%)$ & $02(7,4 \%)$ & --- \\
\hline
\end{tabular}

CGO: chronic gastritis only. * $1+$ : mild, $2+$ : moderate and $3+$ : marked. $P>0,005$ 


\section{DISCUSSION}

Chronic gastritis histologically associated to H. pylori is characterized by infiltration of the lamina propria by chronic inflammatory cells, presence of lymphoid follicles, intestinal metaplasia and varying degrees of infiltration by polymorphonuclear cells that is indicative of inflammatory activity ${ }^{(2)}$. However, some studies have reported that such isolated or combined histological findings have neither sensitive nor specific values enough to predict the diagnosis of this bacterium, and more specific techniques may be required for $H$. pylori detection as Giemsa staining or Warthin-Starry silver impregnation technique ${ }^{(16,18)}$.

Lymphoid follicles that have been described in a great number of gastric biopsies from infected patients with $H$. pylori-associated gastritis may be of a long-time persistence despite further bacteria eradication ${ }^{(9)}$. In our study, this finding was present in $35 \%$ of H. pylori-positive cases, and in $3.6 \%$ of the cases without the bacterium, being associated with bacteria concentration $(P=0.001)$.

Some studies have shown that intestinal metaplasia is less frequent in $H$. pylori non-infected patients ${ }^{(19,21)}$. However, our study found that $20.5 \%$ of biopsy specimens identified as $H$. pylori revealed intestinal metaplasia with no significative differences related to the concentration of bacteria $(P=0.08) .32 .5 \%$ were cases without bacteria in accordance with FAIGEL et al. ${ }^{(7)}$ study that showed no association between this finding and the presence of $H$. pylori.

Epidemiological studies have show a three to six-fold increased risk to developing gastric cancer in $H$. pylori sero-positive subjects $^{(22)}$. In the Correa model (apud WYATT) ${ }^{(22)}$ a sequence of changes is envisaged from normal mucosa through gastritis, atrophy, intestinal metaplasia, and dysplasia, to malignancy. LADEIRA et al. ${ }^{(13)}$ reported that a significantly higher level of DNA damage was associated to an increased intensity of gastritis and not to an increased concentration of $H$. pylori.

The present study report the presence of regenerative cell atypias in $27 \%$ of the $H$. pylori cases and in only $5 \%$ of the cases without the bacterium. There was an increased incidence of mild cellular atypia (in $68.7 \%$ of the biopsy specimens) and association between the degree of cellular atypia and the concentration of $H$. pylori, which has not been reported so far. The association between atypia and intestinal metaplasia which is very much associated to the evolution to gastric carcinoma has only occurred in six case reports, in which four cases the concentration of $H$. pylori was $1+$ and two were $2+$.

According to MENDONÇA et al. ${ }^{(15)}$, the isolated finding with the higher specificity is the presence of polymorphonuclear cells in the stroma (activity) however, it has low sensitivity. Different grades of inflammation intensity have already been observed in H. pylori infected and non-infected patients reporting that the diagnosis for this bacterial colonization cannot be based only on patterns of inflammation ${ }^{(10)}$.

In our study, the presence of activity was even more frequent in the cases negative for bacteria $(72.3 \%)$ than in $H$. pylori positive cases $(53 \%)$, as observed in PHULL et al. study ${ }^{(17)}$.

Some authors have been reporting a association between the activity grade and the bacterial concentration ${ }^{(1,6,11,12,20)}$ although some of them have reported that only this finding could have an association with the concentration of $H$. pylori $i^{(12,20)}$. Although in our study the incidence of activity was higher in biopsy specimens without the bacterium, their marked activity prevailed over the biopsy specimens that had a concentration of bacteria of $3+(42 \%)$.

Close attention was paid to an increasing number of cases with marked activity among those found without bacteria $(14.4 \%)$ than to the cases with bacterial concentration of $1+(9.8 \%)$, and the small number of cases observed in the concentration of $2+$ $(3.7 \%)$. Such fact may be due to the production of interleukin-10 (IL-10) that along with the tumor necrosis factor (TNF)-alpha are increased in H. pylori infections ${ }^{(2)}$. IL-10 may be a protective factor in limiting the tissue damage caused by inflammation that can contribute; however, to a failure of the immune response to eliminate the organism ${ }^{(2)}$, thus, great concentrations of $H$. pylori could inhibit the proliferation of mononuclear cells and stimulate a more intense compensatory inflammatory response at the expense of polymorphonuclear cells.

However, few studies have been carried out to evaluate the combining frequency of histological findings related to the presence of $H$. pylori showing that as the number of combinations increases and sensitivity to $H$. pylori becomes raised, specificity tends to decrease ${ }^{(15)}$.

We have observed a discrete increase in the number of combinations of histopathological findings related to the presence of $H$. pylori; biopsy specimens without bacteria presented a combination of three findings at the latest, while the association between chronic gastritis and activity (in 34 cases), and activity and intestinal metaplasia (in 24 cases) was the most frequent. A higher number of a combination of histopathological findings with regard to the $H$. pylori concentration was not observed.

Although none of these cases of bacterial concentration of $3+$ presented only chronic gastritis, most of them $(68,42 \%)$ have presented a combination of the two findings, and the association between chronic gastritis and activity was the most frequent. None of the biopsy specimens with this same concentration have been reported to present a combination of the five findings.

\section{CONCLUSION}

The presence of lymphoid follicles and regenerative cell atypia is more associated with the cases of chronic gastritis with $H$. pylori, but intestinal metaplasia is not associated with the $H$. pylori infection.

Inflammatory activity is the most frequent finding regardless of $H$. pylori presence. And the association of activity and chronic gastritis is the most frequently.

Grade of inflammatory activity and regenerative cell atypia are associated with a higher concentration of $H$. pylori.

Determining the presence of $H$. pylori in gastric biopsy specimens for its therapeutic implications for chronic gastritis may be more important than determining its concentration since it is not associated with the number of gastric mucosa findings.

However, regardless of the presence of $H$. pylori, quantifying the grade of gastritis activity is important since this finding is related to an increase in damages to DNA and, consequently, to a higher risk for the development of gastric cancer. 
Nai GA, Parizi ACG, Barbosa RL. Associação entre a concentração de Helicobacter pylori e a freqüência de combinação de alterações histopatológicas em biopsias gástricas. Arq Gastroenterol. 2007;44(3):240-3.

RESUMO - Racional - O Helicobacter pylori é o agente infeccioso com maior prevalência em todo o mundo. Cerca de $90 \%$ dos pacientes com gastrite crônica têm infecção por esta bactéria. Alguns estudos demonstram correlação entre a concentração de $H$. pylori e o grau de severidade e atividade da gastrite. Objetivos - Avaliar a associação entre a concentração de H. pylori e a freqüência de combinações de alterações no exame histopatológico. Métodos - Foram analisadas, retrospectivamente, 200 biopsias gástricas endoscópicas consecutivas com o diagnóstico de gastrite crônica. A pesquisa de H. pylori foi realizada através da coloração de Warthin-Starry e foram analisados os seguintes parâmetros (segundo o sistema de Sydney): 1. infiltração de polimorfonucleares no cório e no epitélio (atividade), graduada em leve, moderada e acentuada; 2. presença de folículos linfóides; 3 . presença de metaplasia intestinal; 4. presença de atipias celulares regenerativas, graduadas em leve, moderada e acentuada; e 5. concentração de H. pylori no muco que recobre o epitélio foveolar. Resultados - A associação mais freqüente foi de gastrite crônica e atividade, independente da concentração de $H$. pylori. Associação de cinco achados histopatológicos numa mesma biopsia não ocorreu nos casos com maior concentração de H. pylori. Conclusão - Este estudo não demonstrou associação entre a concentração de H. pylori e aumento no número de alterações histopatológicas encontradas na mucosa gástrica, mostrando ser importante referir sua presença e não sua concentração.

DESCRITORES - Gastrite. Helicobacter pylori. Infecções por Helicobacter. Biopsia

\section{REFERENCES}

1. Alam K, Schubert TT, Bologna SD, Ma CK. Increased density of Helicobacter pylori on antral biopsy is associated with severity of acute and chronic inflammation and likehood of duodenal ulceration. Am J Gastroenterol. 1992;87:424-8.

2. Bodger K, Wyatt JI, Heatley RV. Gastric mucosal secretion of interleukin-10: relations to histopathology, Helicobacter pylori status, and tumour necrosis factor alfa secretion. Gut. 1997;40:739-44.

3. Dixon MF. Pathophysiology of Helicobacter pylori infection. Scand J Gastroenterol. 1994;29 (Suppl 201):7-10.

4. Dixon MF, Genta M R, Yardley J H, Correa P. Classification and grading of gastritis. Am J Surg Pathol. 1996;20:1161-81.

5. Dixon MF, Genta RM, Yardley JH, Correa P. Histological classification of gastritis and Helicobacter pylori infection: an agreement at last? Helicobacter. 1997;2 (Suppl 1):s17-s24.

6. Duarte IG, Schultz MH, Chianale JB, Bravo RC, Vergara MT, Llanos JL, Sánches RB, Andrade LM, Villarroel LD. Análisis histopatológico semicuantitativo da la gastritis crónica: índice de extensión y grado. Rev Med Chile. 1996;124:1200-6.

7. Faigel DO, Furth EE, Childs M, Goin J, Metz DC. Histological predictors of active Helicobacter pylori infection. Dig Dis Sci. 1996;41:937-43.

8. García JA. Gastritis crónica por Helicobacter pylori. Patologia. 1997;35:89-91.

9. Genta RM, Hamner W. The significance of lymphoid follicles in the interpretation of gastric biopsy specimens. Arch Pathol Lab Med. 1994;118:740-3.

10. Hui PK, Chan WI, Cheung PS, Chan JK, Ng CS. Pathologic changes of gastric mucosa colonized by Helicobacter pylori. Hum Pathol. 1992;23:548-56.

11. Jan CM, Wu D, Su Y, Wang W, Liu C, Lin S, Chen C. Evaluation of severity of Helicobacter pylori infection with urease test: its correlation with histopathology and bacterial density. Kaohsiung J Med Sci. 1995;11:650-3.

12. Khulusi S, Mendall MA, Pate P, Levy J, Badve S, Northfield TC. Helicobacter pylori infection density and gastric inflammation in duodenal ulcer and non-ulcer subjects. Gut. 1995;37:319-24.

13. Ladeira M, Rodrigues MA, Domingues M, Pinto CL, Prado RP, Camargo EA, Pinhal D, Queiroz DM, Guerrra J, Ribeiro ML, Salvadori DM. Oxidative DNA damage in patients with gastritis and gastric cancer infected by Helicobacter pylori. [resumo 11.35] J Bras Patol. 2005;41(3 Suppl):84
14. Luthra GK, DiNuzzo AR, Gourley WK, Crowe SE. Comparison of biopsy and serological methods of diagnosis of Helicobacter pylori infection and the potential role of antibiotics. Am J Gastroenterol. 1998;93:1291-6.

15. Mendonça AL, Meneses AC, Chapadeiro E. Sensibilidade e especificidade de alterações histológicas da mucosa gástrica antral para o diagnóstico do Helicobacter pylori. J Bras Patol. 1999;35:125-32.

16. Nogueira AM, Cabral MM, Carvalho AS, Oliveira CA, Queiroz DM, Oliveira AM, Rocha GA, Mendes EM, Magalhães PP, Castro AC, Paturle P. Gastrite associada ao Helicobacter pylori em adultos e crianças: estudo comparativo. J Bras Patol. 2000;36:110-7.

17. Phull PS, Price AB, Stephens J, Rathbone BJ, Jacyna MR. Histology of chronic gastritis with or without duodenites in patients with Helicobacter pylori infection. J Clin Pathol. 1996;49:377-80.

18. Reyes E. Indentificación histopatológica del Helicobacter pylori. Patologia. 1997;35:84-8.

19. Rugge M, Di Mario F, Cassaro M, Baffa R, Farinati F, Rubio Jr J, Ninfo V. Pathology of the gastric antrum and body associated with Helicobacter pylori infection in nonulcerous patients: is the bacterium a promoter of intestinal metaplasia? Histopathology 1993;22:9-15.

20. Stolte M, Stadelmann O, Bethke B, Burkard G. Relationship between the degree of Helicobacter pylori colonisation and the degree and activity of gastritis, surface epithelial degeneration and mucus secretion. Z Gastroenterol. 1995; 33:89-93.

21. Wang CC, Wu MS, Wang HH, Wang HP, Lee WC, Shun CT, Lin JT. Helicobacter pylori infection and age on the development of intestinal metaplasia - a multiple logistic regression analysis. Hepatogastroenterology. 1998; 45:2234-7.

22. Wyatt JI. Histopathology of gastroduodenal inflammation: the impact of Helicobacter pylori. Histopathology. 1995;26:1-15. 